\title{
Rudolph Nureyev
}

\author{
March 17, 1938-January 6, 1993
}

Dancer-choreographer-conductor Rudolf Hametovich Nureyev was born on a train near Irkutsk, in east-central Russia. His father, a military man, never supported Nureyev's desire to dance, wishing only that his son would join him in the military.

Young Nureyev's passion drew him to local amateur folk dance groups in his home town of Ufa, and his obvious talent led him to study at the Leningrad Choreography School, where his primary training from 1955 to 1958 was with Alexander Pushkin. Success in a Moscow dance competition brought him contract offers from the Kirov, Bolshoi, and Stanislavsky theatres; he chose the Kirov. He entered the company in 1958 as a soloist, and was greatly praised for his talent. But Nureyev's adventurous spirit and sense of uniqueness led to continuous conflict with the authorities; even in his early twenties he was creating his own style and developing the personal charisma that made him a legend to millions.

In May of 1961, while performing at the Paris Opera with the Kirov Ballet, Nureyev danced to great critical acclaim, but was accused by the Russian authorities of being "too friendly" with the French press and public. As members of the Kirov company were about to board a plane at Le Bourget airport to depart for a performance in London, Soviet officials tried to put Nureyev on a flight to Moscow. He eluded the officials and, throwing himself into the arms of a French inspector, asked for asylum. On June 17, 1961, at the tender age of twenty-three, Rudolf Nureyev burst upon the Western dance world, changing it forever.

Nureyev became the rebel of his era. The Soviet system could not contain his creative drive and urge to explore his beloved dance to the fullest; in the West he not only made ballet "in," but raised the standard of male dancing worldwide.

After his defection Nureyev joined the Grand Ballet du Marquis de Cuevas, performing the "Bluebird Pas de Deux" with Rosella Hightower. At the invitation of British prima ballerina Margot Fonteyn, on November 2, 1961 he made his English debut, again dancing with Hightower. He also performed a solo choreographed by Sir Frederick Ashton for the occasion (a gala at the Royal Drury Lane).

A dispute with de Cuevas brought Nureyev to the United States in 1962, where he guested with Ruth Page's Chicago Opera Ballet and appeared with Sonia Arova on national television. Later that year one of the most brilliant partnerships in ballet was created when Nureyev was invited to become guest artist with London's Royal Ballet and principal partner of Margot Fonteyn. This partnership lasted for many years-until 1979, when Fonteyn was sixty years old. Fonteyn herself stated that dancing with "Rudi" had brought her own artistry to new heights.

Already known for his dazzling virtuosity and electrifying charisma, Nureyev himself grew artistically during his years with Fonteyn, creating roles such as Ashton's Marguerite and Armand in 1963, and further refining and redefining the nineteenth-century classics, with which he was closely identified. At his peak his technical polish and adherence to classical tradition, combined with a daring and sensual provocativeness, made him a living legend.

During the 1960s and 1970s Nureyev created roles for all the world's leading choreographers, including Roland Petit's Paradise Lost (1967), Rudi Van Danzig's The Ropes of Time (1970), and Maurice Bejart's Songs of a Wayfarer (1971). Even adventurous explorations into the modern techniques of Martha Graham, Murray Louis, and Paul Taylor attracted him.

As early as 1963 Nureyev began setting productions for ballet companies throughout the world. His first major production was for the Royal Ballet, beginning with $L a$ Bayadère. He also staged Raymonda, Swan Lake, Don Quixote, Sleeping Beauty, and Nutcracker for not only the Royal Ballet, but the Australian Ballet, Zurich Ballet, Paris Opera Ballet, and American Ballet Theatre. Nureyev felt that these productions connected him to his roots at the Maryinsky (Kirov) Theatre, which he believed to be the foundation of all that had given his life meaning.

During the 1970s and 1980s Nureyev explored other mediums, trying his hand at acting, movies (Valentino and $E_{x}$ posed), musical comedy (The King and I), and, most recently, at conducting - with orchestras in Vienna, Athens, Budapest, and Russia.

The last large ballet Nureyev supervised was a 1992 production of La Bayadère for the Paris Opera Ballet, where he had been artistic director from 1980 to 1989. Too. weak to stand because of a serious illness related to recent heart surgery, he received a standing ovation at the triumphant opening performance and was awarded the title of Commander des l'ordre des Arts et Lettres by France's Minister of Culture. It was a nostalgic moment because it was in $\mathrm{La}$ Bayadere in which Nureyev, at age twenty, had danced his first major role with the Kirov.

His great pride and devotion to ballet shone until the end, and he was fond of saying, "My nationality is dancer ... my country, the stage."

Alaine Haubert American Ballet Theatre and University of Hawaii 